(Mavka/CDC Camino, Belko/CDC Rosalee and Mavka/Niger Wally) were studied. The study object was the performance and suitability for mechanized harvesting as well as traits that determine them. The breeding was conducted according to the full breeding design. We conducted multiple individual selections, starting with $\mathrm{F}_{2}$. We used experimental-field and laboratoryanalytical methods and statistical processing of data on a PC.

Results and discussion. The degree of phenotypic dominance of the plant height in $\mathrm{F}_{1}$ hybrids varied 9.4 to -1.75 , of the performance and its constituents -2.7 to -1.5 . The frequency of probable transgressions in $\mathrm{F}_{2}$ was within $16.5-32.0$ and $0-14.7 \%$, respectively, with a coefficient of variation ranging $17.5 \%$ to $61.9 \%$. The index traits were less variable. In the $\mathrm{F}_{3}$ Mavka/CDC Camino the share of performance-positive transgressions was $50.0 \%$; in the $\mathrm{F}_{3}$ Belko/CDC Rosalee it was $12.0 \%$ related to the number of transgressive forms in $\mathrm{F}_{2}$. In the $\mathrm{F}_{4}$ Mavka/CDC Camino, it increased to $66.1 \% .57 .1 \%$ of the $\mathrm{F}_{5}-\mathrm{F}_{6}$ breeding lines gave higher yields than that from check variety Pervomaiska. In $64.3 \%$ of the breeding lines, the yield stability exceeded $70 \% ; 39.2 \%$ of the accessions were better $(81.4-97.1 \%)$ than the check variety $(76.5 \%)$.

Conclusions. Intravariety hybridization was proved to be an effective method for the crop breeding. It is recommended to select idiotypes from hybrid populations from crossing forms have contrasting traits, starting with $\mathrm{F}_{3}$; it is advisable to use the harvest index as a selection criterion.

Key words: common bean, breeding, variety, trait, hybridization, intervariety hybrids, inheritance of traits, heterosis, breeding accession.

UDC 633.522: 631.52

\title{
VARIABILITY OF CANNABINOID CONTENTS DEPENDING ON BREEDING METHODS
}

Laiko I.M., Mishchenko S.V., Kyrychenko A.I.

Institute of Bast Crops NAAS, Ukraine

Breeding methods are proposed for reducing psychotropic tetrahydrocannabinol, stabilizing the absence of cannabinoids in cannabis cultivars - populations and increasing the contents of cannabidiol, cannabigerol and cannabichromen gaining advantage from valuable collection accessions.

Key words: breeding, cultivar, mutagenesis, inbreeding, cannabinoids, performance.

Introduction. In cannabis breeding, a number of techniques have been developed. The techniques allow for the assessment, stabilization and consolidation of the contents or absence of cannabinoid compounds. Current studies are focused on developing approaches to expansion of ranges of genotype expression with subsequent stabilization of valuable traits in the offspring [1].

Literature review and problem articulation. For almost 50 years of breeding for reduction in the narcotic activity of industrial hemp, Ukrainian scientists have achieved the lowest level of tetrahydrocannabinol (THC) in the world $-0.000-0.001 \%$. It is unique that in these studies the dominant trait of the THC presence has been brought to high homozygosity of the population for this trait by selections and targeted cross-pollination of plants without cannabinoids at all. In such a population, there are no plants with a THC content above 1 point, although initially there

(C) I.M. Laiko, S.V. Mishchenko, A.I. Kyrychenko. 2021.

ISSN 1026-9959. Селекція і насінництво. 2021. Випуск 119. 
were plants with 3 to 10 points and higher. The breeding effectiveness is attributed to new methods of evaluation of breeding material, selection of elite plants, investigation of mechanisms of formation and accumulation of cannabinoids in plant organs during different phases of vegetation [2-5].

THC-free cultivars of industrial hemp have opened the prospects for a transition to a new level of increasing the cultivars "e performance in terms of oil and fiber contents as well as of seed and stem yields. New hemp cultivars, Hlesiia, Mykolaichyk, Hlukhivski 51, and Hlukhivski 85, are noticeable for these unique biological features [6-9].

In light of the curative properties of some non-psychotropic cannabinoids $[10,11]$, the creation of medical cannabis (in compliance with current laws) has become relevant. The growing interest in such cannabis requires a quick solution, and therefore exploratory studies are conducted to identify valuable accessions with high contents of cannabidiol (CBD), cannabigerol (CBG), cannabichromene (CBC) and other non-psychotropic compounds $[12,13]$. It is known that inbreeding results both in aligned homozygous lines and in heterozygous material, and this can become a methods of selecting valuable plants and stabilizing the offspring populations [14]. Gamma irradiation of seeds also causes genotypic changes.

Purpose and objectives. To reveal new possibilities for the expression of cannabis genotypes to obtain starting material with increased contents of non-psychotropic cannabinoids, without THC and stabilized biological traits.

Material and methods. In our study, we took Ukrainian hemp cultivars, the populations of which were distinguished by high stability of cannabinoid contents in comparison with foreign cultivars, as a basis. The study was carried out using breeding, biochemical and statistical methods: physical mutagenesis, inbreeding, individual selection, thin-layer and gas-liquid chromatography to evaluate plants for cannabinoids (HP 6890 Series Hewlett Packard chromatograph using an internal standard).

Results and discussion. Using the developed breeding methods, today it is possible both to stabilize a population of a cross-pollinated crop and to change the vector of the cannabinoid contents, i.e. to increase or to decrease them. Let us consider changes in the cannabinoid contents under the influence of gamma irradiation, self-pollination and selection of plants for the absence or increase in cannabinoids without boosting the psychotropic activity of industrial hemp cultivars.

Seeds of several cannabis cultivars gamma irradiated at a dose of 200 or 150 Gy at the Daqing branch of the Academy of Sciences of Heilongjiang Province (China) were studied in order to identify mutant beneficial forms. In the process of obtaining $\mathrm{M}_{1}-\mathrm{M}_{3}$, the cannabinoid contents were also monitored in order to identify new material with high CBD and CBG levels.

It was found that the higher dose of irradiation (200 Gy) of Hlesiia cultivar expanded the cannabinoid content variability range from 0 to 10 points, with accumulation of the maximum amounts (the original plants contained no cannabinoids at all). Of 10 analyzed plants, only one plant had no cannabinoids at all; 7 plants contained trace or small (up to 3 points) amounts of these compounds (from thin-layer chromatography data); and there were 2 plants with a high content of THC or CBD. Moreover, one of them can be referred to the Central European type - 10 points of $\mathrm{CBD}$ and the minimum of THC, while the other was not a typical southern type with a high content of THC and a small amount of CBD (trace amount). This plant is a mutant by origin $\left(\mathrm{M}_{4}\right)$ (Table 1).

The lower dose of irradiation (150 Gy) did not affect the genotypic trait of the cannabinoid absence in 11 plants during their investigation up to $\mathrm{M}_{4}$. The same pattern was observed for Zolotonoshskaya 15 (150 Gy). The cultivar remained stable in terms of the absence of cannabinoids during propagation up to $\mathrm{M}_{4}$.

Among the plants of the Chinese cultivar, CK (irradiated with $200 \mathrm{~Gy}$ ), segregation was seen, and four plants with a THC content of 1-3 points and seven plants with a THC content of 5-10 points appeared. At the same time, the initial plants of this cultivar contained THC of not below 10 points (Table 2). 
Cannabinoid contents in $M_{3}$ Hlesiia plants (200 Gy)

\begin{tabular}{cccccc}
\hline \multirow{2}{*}{ Plant No } & \multicolumn{5}{c}{ Cannabinoid content, point } \\
\cline { 2 - 6 } & CBD & THC & CBN & CBC & CBG \\
\hline 1 & 0 & 0 & 0 & 0 & 0 \\
2 & 0.25 & 0 & 0 & 0 & 0 \\
3 & 10 & 5 & 0.25 & 5 & 6 \\
4 & 0.5 & 0 & 0 & 0 & 0 \\
5 & 0.5 & 10 & 2 & 5 & 0 \\
6 & 0.5 & 2 & 0 & 0.25 & 0 \\
7 & 0.25 & 0.25 & 0 & 3 & 6 \\
8 & 0.5 & 3 & 0 & 3 & 0 \\
9 & 1 & 0.5 & 0 & 1 & 0 \\
10 & 1 & 0.5 & 0 & 3 & 0 \\
\hline Average & 1.45 & 2.12 & 0.22 & 2.02 & 1.2 \\
\hline
\end{tabular}

Table 2

Cannabinoid contents in $M_{3} C K$ plants (200 Gy)

\begin{tabular}{cccccc}
\hline \multirow{2}{*}{ Plant No } & \multicolumn{5}{c}{ Cannabinoid content, point } \\
\cline { 2 - 6 } & CBD & THC & CBN & CBC & CBG \\
\hline 1 & 0.5 & 1 & 0 & 0.5 & 0 \\
2 & 0.25 & 10 & 2 & 6 & 3 \\
3 & 1 & 6 & 0.25 & 6 & 3 \\
4 & 1 & 6 & 0.25 & 6 & 3 \\
5 & 0.5 & 5 & 0 & 1 & 0.5 \\
6 & 1 & 10 & 0.5 & 8 & 4 \\
7 & 0.5 & 10 & 0.5 & 8 & 4 \\
8 & 0 & 6 & 0.5 & 6 & 0.5 \\
9 & 0 & 7 & 0.5 & 2 & 0 \\
10 & 0.5 & 3 & 0 & 2 & 0 \\
11 & 0.5 & 3 & 0 & 3 & 0 \\
12 & 0.5 & 3 & 0 & 2 & 0 \\
\hline Average & 0.52 & 5.83 & 0.38 & 5.05 & 1.50 \\
\hline
\end{tabular}

Gamma rays at a dose of 200 Gy disrupt the genotypic relationships between cannabinoids, with accumulation of their minimum or maximum amounts. Lowering the irradiation dose to $150 \mathrm{~Gy}$ does not destabilize the population in terms of the cannabinoid contents. These results confirm the possibility of using this method in breeding to identify valuable economic traits in collection hemp cultivars with high cannabinoid contents and in subsequent individual selection of plants with a lower amount of THC, with their involvement in the breeding process.

In the process of self-pollination of plants with the THC level of 1 to 4 points, both THCfree plants and plants containing THC of $>10$ points were identified. Along with plants of the Central European type, where a high content of CBD is combined with the minimum content of THC (for example, 6 points and 0.5 points, 10 and 1 points, respectively), three plants of the southern type, where CBD is significantly lower than THC (2-3 points of CBD, $>10$ points of THC), appeared. Inbreeding can be also used in breeding both to create inbred lines that are homozygous for the „no cannabinoids ${ }^{e e}$ trait and to identify lines with increased contents of CBD, $\mathrm{CBG}$ and $\mathrm{CBC}$.

At the beginning of breeding for reduced narcotic activity, some collection cultivars contained CBD and THC in the range of 0.952-2.249 and 0.008-0.080\%, respectively. A lot of early-bred and modern cultivars (French, Polish, Hungarian, German) show a high population variability of the cannabinoid contents, proving that no systemic breeding was conducted to stabilize these traits in the populations of these cultivars (Table 3). 
CBD and THC contents in collection hemp cultivars, 2019-2020 average

\begin{tabular}{lccc}
\hline \multirow{2}{*}{ Cultivar } & \multicolumn{2}{c}{ Content, \% } \\
\cline { 3 - 4 } & & CBD & THC \\
\hline Yuso 1 & 1.668 & 0.008 \\
Bernburgskaya Odnodomnaya & 1.779 & 0.011 \\
Yus 9 & 0.952 & 0.074 \\
Fedora 19 & 2.249 & 0.080 \\
Futura 77 & 1.628 & 0.060 \\
& LSD $_{05}$ & 0.150 & 0.004 \\
\hline
\end{tabular}

High homogeneity of populations in terms of the formation and accumulation of cannabinoids is only intrinsic to monoecious hemp cultivars bred by the Institute of Bast Crops of NAAS. These non-narcotic cultivars were created by the developed unique methods of breeding, assessing and analyzing plants for the contents of cannabinoids on the basis of fixing the „no cannabinoid at alle trait for ten years. It was found that the homozygosity of a population primarily depended on the control of targeted cross-pollination between cannabinoid-free plants using an express testing plants for these compounds prior to anthesis onset and subsequent analysis of the selected elite plants by thin-layer chromatography (Table 4).

Table 4

CBD and THC contents in modern hemp cultivars, 2019-2020

\begin{tabular}{lcccccc}
\hline \multirow{2}{*}{ Cultivar } & \multicolumn{2}{c}{2019} & \multicolumn{3}{c}{ CBD and THC contents, \% } & \multicolumn{2}{c}{ Average } \\
\cline { 2 - 7 } & CBD & THC & CBD & THC & CBD & THC \\
\hline Hliana & 0.056 & 0.007 & 0.091 & 0.000 & 0.074 & 0.004 \\
Mykolaichyk & 0.128 & 0.000 & 0.188 & 0.008 & 0.158 & 0.004 \\
Hlesiia & 0.017 & 0.010 & 0.010 & 0.000 & 0.014 & 0.005 \\
Hlukhivski 51 & 0.010 & 0.028 & 0.026 & 0.000 & 0.018 & 0.014 \\
Hlukhivski 85 & 0.007 & 0.022 & 0.015 & 0.016 & 0.011 & 0.019 \\
\multicolumn{1}{c}{ LSD 05} & & & & & 0.008 & 0.002 \\
\hline
\end{tabular}

Given the relevance of creating hemp varieties with therapeutic properties, breeding methods have been developed to shift the balance of ,no cannabinoid at all "e towards a genetically determined increase in one of the cannabinoids (CBD, $\mathrm{CBG}, \mathrm{CBC})$ combined with eliminated psychotropic activity (the THC content does not exceed $0.08 \%$ ).

Studies of cannabinoid accumulation revealed differences in their formation during the growing period. Thus, in a population with a high CBG content, its content ranged 1.037 to $1.355 \%$, in large leaves during the mass flowering phase, and a 3.5 -fold increase in the CBG content was observed in small leaves and perianths (inflorescences) 38 days later, during the seed ripening onset (Table 5).

Table 5

Cannabinoid accumulation during the growth and development of Vik 2020 plants, 2019-2020 average

\begin{tabular}{ccccccc}
\hline \multirow{2}{*}{ Family No } & \multicolumn{3}{c}{ Mass flowering, large leaves } & \multicolumn{3}{c}{ Seed ripening onset, small leaves and } \\
& \multicolumn{3}{c}{ perianths } \\
\cline { 2 - 7 } & CBD & THC & CBG & CBD & THC & CBG \\
\hline 138 & 0.234 & 0.028 & 1.311 & 0.291 & 0.029 & $4.057^{*}$ \\
139 & 0.112 & 0.021 & 1.037 & 0.090 & $0.000^{*}$ & $3.850^{*}$ \\
140 & 0.267 & 0.032 & 1.355 & 0.261 & $0.014^{*}$ & $4.700^{*}$ \\
Average & 0.204 & 0.027 & 1.234 & 0.214 & 0.014 & $4.202^{*}$ \\
\hline
\end{tabular}

Note. $*$ - significant difference (between phenological phases), $\mathrm{p} \leq 0.05$ (Student's t-test). 
There was a 2-fold increase in the accumulation of cannabidiol in plants from anthesis to the seed ripening onset, that is, it is accumulated less intensively, and this is only noted during the perianth formation, which is associated with an augmented function of the excretory system glandular hairs (trichomes).

Based on the fact that the maximum accumulation of cannabinoids occurs during the seed ripening onset, and, in particular, their synthesis is the most intensive in perianths and small leaves, it is possible to evaluate the prospects for creating hemp cultivars with a branched diamond-shaped inflorescence, which will provide, in addition to a high content of one or another cannabinoid, an increased yield of plant biomass.

Conclusions. Gamma irradiation of seeds makes it possible to obtain genetic mutations of contents of different cannabinoid compounds and to select valuable ones. Furthermore, in the process of self-pollination, inbred lines both with a high homogeneity of the „no cannabinoid at

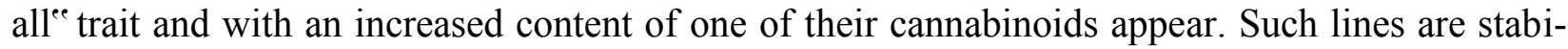
lized through individual selection into populations of new breeding material. When creating cultivars with therapeutic properties, one should take into account the main criteria for such breeding material, which should have consistently high levels of $\mathrm{CBD}, \mathrm{CBG}, \mathrm{CBC}$ without narcotically active tetrahydrocannabinol (in compliance with current laws) and produce an increased biomass of plants.

\section{Список використаних джерел}

1. Salentijn E.M.J., Zhang Q., Amaducci S., Yang M., Trindade L.M. New developments in fiber hemp (Cannabis sativa L.) breeding. Ind. Crop. Prod. 2015. Vol. 68. P. 32-41. DOI: 10.1016/j.indcrop.2014.08.011

2. Мигаль М.Д., Кмець І.Л, Лайко І.М. Трихоми і канабіноїди конопель. Суми: ФОП Щербина I.В. 2017. 228 с.

3. Міщенко С.В. Кореляційні звеязки між основними канабіноїдними сполуками рослин сучасних безнаркотичних сортів конопель. Вісник Полтавської державної аграрної академії. 2012. № 2. С. 65-69. DOI: 10.31210/visnyk2012.02.14

4. Міщенко С.В., Лайко I.M. Накопичення канабідіолу в онтогенезі рослин технічних (промислових) конопель. Plant Varieties Studving and Protection. 2018. Vol. 14, № 4. Р. 390-399. DOI: 10.21498/2518-1017.14.4.2018.151902

5. Layko I.M., Vyrovets V.H., Beherec O., Kirichenko H.I., Mishchenko S.V., Kmets I.L. The Ukrainian and French breeders operations to elimination of drug property of sowing hemp (Cannabis sativa L.). Agrobiodiversity for Improving Nutrition, Heaith and Life Quality: Scientific Proceeding. Nitra, 2015. Part II. P. 414-417.

6. Вировець В.Г., Лайко I.М., Верещагін I.В., Тимчук С.М., Поздняков В.В. Перспективи селекції на оптимізацію жирнокислотного складу олії сучасних сортів ненаркотичних конопель. Селекциiя і насінницттво. 2011. Вип. 100. С. 247-254. DOI: 10.30835/24137510.2011 .66619

7. Laiko I.M., Vyrovets V.H., Kyrychenko H.I., Mishchenko S.V., Kmets I.L. Contemporary fibre level in non-narcotic varieties of hemp (Cannabis sativa L.). Sel. Nasinn. 2015. Iss. 107. P. 68-75. DOI: $10.30835 / 2413-7510.2015 .54033$

8. Laiko I.M. The uniqueness of biological characteristics of technical hemp and prospects for its practical use. Sel. Nasinn. 2020. Iss. 117. P. 80-90. DOI: 10.30835/24137510.2020 .206985

9. Maumevičius E., Burbulis N., Jankauskienė Z., Blinstrubienė A., Laiko I. Sèjos ir tręšimo normų poveikis sèjamosios kanapès (Cannabis sativa L.) produktyvumui. Žemés ükio mokslai. 2019. T. 26. Nr. 2. P. 72-82. DOI: 10.6001/zemesukiomokslai.v26i2.4061

10. Rong C., Lee Y., Carmona N.E. Cha D.S., Ragguett R.-M., Rosenblat J.D., Mansur R.B., Ho R.C., McIntyre R.S. Cannabidiol in medical marijuana: Research vistas and potential opportunities. Pharmacol. Res. 2017. Vol. 121. P. 213-218. DOI: 10.1016/j.phrs.2017.05.005

11. Deiana S. Potential medical uses of cannabigerol: a brief overview. Handbook of Cannabis and Related Pathologies: Biology, Pharmacology, Diagnosis, and Treatment / V.R. Preedy 
(Ed.). Cambridge, MA: Academic Press, 2017. P. 958-967. DOI: 10.1016/B978-0128007563.00115-0

12. Кириченко Г.І., Лайко I.M., Міщенко С.В. Аналіз колекційних зразків Cannabis sativa L. за вмістом канабіноїдних сполук і хемотипом. Генетичні ресурси рослин. 2019. № 25. C. 115-128. DOI: 10.36814/pgr.2019.25.09

13. Лайко I.М., Міщенко С.В., Орлов М.М., Маринченко I.О., Шкурдода С.В., Пасічник В.В. Перспективи переорієнтації селекції конопель для створення сортів медичного напряму використання. Наукові праці Інституту біоенергетичних культур і иукрових буряків. 2015. Вип. 23. С. 107-111.

14. Міщенко С.В., Лайко І.М. Визначення рівня стабільності ознаки відсутності канабіноїдів у конопель шляхом самозапилення. Новітні технології вирощування сільськогосподарських культур: наукові праці Інституту біоенергетичних культур і цукрових буряків НААН. 2012. Вип. 14. С. 487-490.

\section{References}

1. Salentijn EMJ, Zhang Q, Amaducci S, Yang M, Trindade LM. New developments in fiber hemp (Cannabis sativa L.) breeding. Ind. Crop. Prod. 2015; 68: 32-41. DOI: 10.1016/j.indcrop.2014.08.011

2. Myhal MD, Kmets IL, Layko IM. Hemp trichomes and cannabinoids. Sumy: FOP Shcherbyna IV, 2017. $228 \mathrm{p}$.

3. Mishchenko SV. Correlations between major cannabinoid compounds in plants of modern non-narcotic hemp varieties. Visnyk Poltavskoyi derzhavnoyi agrarnoyi akademiyi. 2012; 2: 65-69. DOI: 10.31210/visnyk2012.02.14

4. Mishchenko SV, Layko IM. Cannabidiol accumulation during the ontogenesis of technical (industrial) hemp plants. Plant Varieties Studving and Protection. 2018; 14(4): 390-399. DOI: 10.21498/2518-1017.14.4.2018.151902

5. Layko IM, Vyrovets VH, Beherec O, Kirichenko HI, Mishchenko SV, Kmets IL. The Ukrainian and French breeders operations to elimination of drug property of sowing hemp (Cannabis sativa L.). Agrobiodiversity for Improving Nutrition, Heaith and Life Quality: Scientific Proceeding. Nitra, 2015. Part II. P. 414-417.

6. Vyrovets VH, Layko IM, Vereshchagin IV, Tymchuk SM, Pozdniakov VV. Prospects of breeding for optimization of fatty acid composition of oil from modern non-narcotic hemp varieties. Sel. Nasinn. 2011; 100: 247-254. DOI: 10.30835/2413-7510.2011.66619

7. Laiko IM, Vyrovets VH, Kyrychenko HI, Mishchenko SV, Kmets IL. Contemporary fibre level in non-narcotic varieties of hemp (Cannabis sativa L.) Sel. Nasinn. 2015; 107: 68-75. DOI: $10.30835 / 2413-7510.2015 .54033$

8. Laiko IM. The uniqueness of biological characteristics of technical hemp and prospects for its practical use. Sel. Nasinn. 2020; 117: 80-90. DOI: 10.30835/2413-7510.2020.206985

9. Maumevičius E, Burbulis N, Jankauskienė Z, Blinstrubienè A, Laiko I. Sejjos ir tręšimo normų poveikis sèjamosios kanapès (Cannabis sativa L.) produktyvumui. Žemès ūkio mokslai. 2019; 26(2): 72-82. DOI: 10.6001/zemesukiomokslai.v26i2.4061

10.Rong C, Lee Y, Carmona NE. Cha DS, Ragguett R-M, Rosenblat JD, Mansur RB, Ho RC, McIntyre RS. Cannabidiol in medical marijuana: Research vistas and potential opportunities. Pharmacol. Res. 2017; 121: 213-218. DOI: 10.1016/j.phrs.2017.05.005

11.Deiana S. Potential medical uses of cannabigerol: a brief overview. In VR Preedy, editor. Handbook of Cannabis and Related Pathologies: Biology, Pharmacology, Diagnosis, and Treatment/ Cambridge, MA: Academic Press, 2017. P. 958-967. DOI: 10.1016/B978-0$128007563.00115-0$

12.Kyrychenko HI, Laiko IM, Mishchenko SV. Analysis of Cannabis sativa L. collection accessions for cannabinoid contens and chemotype. Genetychni resursy roslyn. 2019; 25: 115- 128. DOI: $10.36814 /$ pgr.2019.25.09

13.Laiko IM, Mishchenko SV, Orlov MM, Marynchenko IO, Shkurdoda SV, Pasichnyk VV. Prospects of re-orientation of hemp breeding for creation of pharmaceutical varieties. Naukovi 
pratsi Instytutu bioenerhetychnykh kul'tur i tsukrovykh buryakiv NAAN. 2015; 23: 107-111.

14. Mishchenko SV, Laiko IM. Determination of the level of stability of the sign of absence of cannabinoids in hemp by self-pollination. Novitni tekhnolohiyi vyroshchuvannya sil's'kohospodars'kykh kul'tur: naukovi pratsi Instytutu bioenerhetychnykh kul'tur i tsukrovykh buryakiv NAAN. 2012; 14: 487-490.

\section{МІНЛИВІСТЬ ОЗНАКИ ЗМІСТУ КАНАБІНӦ̈ДІВ ЗАЛЕЖНО ВІД СЕЛЕКЦІЙНИХ ПРИЙОМІВ}

Лайко I.М., Міщенко С.В., Кириченко Г.I.

Інститут лубеяянх культур НААН, Україна

Мета і завдання досліджень. Виявити нові можливості прояву генотипів конопель для отримання вихідного матеріалу з підвищеним вмістом непсихотропних канабіноїдів, відсутністю ТГК і стабілізованими біологічними ознаками.

Матеріал і методи. У своїх дослідженнях ми виходили з того, що за основу брали українські сорти конопель, популяції яких відрізнялися високою стабільністю за ознакою вмісту канабіноїдів, в порівнянні з зарубіжними сортозразками. Дослідження проводили $з$ використанням селекційних, біохімічних та статистичних методів: фізичного мутагенезу, інцухтування, індивідуального добору, тонкошарової та газорідинної хроматографії для оцінки рослин за наявністю канабіноїдів (хроматограф HP 6890 Series Hewlett Packard з використанням внутрішнього стандарту).

Обговорення результатів. Встановлено, що обробка гамма-променями в дозі 200 Гр призводить до порушень генотипических взаємозв'язків між канабіноїдами з проявом їх мінімальних і максимальних кількостей. Зниження дози опромінення до 150 Гр не дестабілізує популяцію за вмістом канабіноїдів.

Метод інцухтування також може бути застосований в селекції при створенні інцухт-ліній, гомозиготних як за ознакою відсутності канабіноїдів, так і для виявлення ліній з підвищеним вмістом каннабідіолу, каннабігеролу, каннабіхромену.

У багатьох сортозразків ранньої і сучасної селекції конопель (французькі, польські, угорські, німецькі) відзначається висока популяційна мінливість ознаки наявності канабіноїдів, що доводить відсутність системної селекційної роботи на стабілізацію цих ознак в популяції. Високою однорідністю популяцій з формування і накопичення канабіноїдів відрізняються тільки сорти однодомних конопель селекції Інституту луб'яних культур НАAН.

Гомозиготність популяції в першу чергу залежить від чинників контролювання спрямованого перезапилення між рослинами 3 повною відсутністю канабіноїдів за допомогою проведення експрес-методу рослин на наявність цих сполук до початку цвітіння і подальшим аналізом відібраних елітних рослин методом тонкошарової хроматографії.

У зв'язку з актуальністю створення сортів конопель 3 терапевтичними властивостями були розроблені методи селекції на зміну балансу відсутності всіх канабіноїдів в бік генетично зумовленого збільшення одного з непсихотропних канабіноїдів: каннабідіолу, каннабігеролу, каннабіхромену з відсутністю психотропної активності (наявність тетрагідроканнабінолу не перевищує $0,08 \%$ ).

Дослідженнями процесів накопичення канабіноїдів були виявлені відмінності в біології формування їх протягом вегетації. Виходячи з того, що максимальне накопичення канабіноїдів доводиться на фазу початку дозрівання насіння i, зокрема, їх найбільше синтезується в оцвітинах і дрібних листках, можна визначити перспективність створення сортів конопель з розгалуженим суцвіттям ромбоподібної форми, що буде забезпечувати поряд $з$ високим вмістом того чи іншого каннабіноїду ще й підвищений урожай рослинної біомаси.

Висновки. Фізичний мутагенез, інцухтування і добір $є$ перспективними селекційними 
прийомами зниження психотропного тетрагідроканабінолу, стабілізації популяцій сортів конопель за відсутності канабіноїдів, підвищення вмісту каннабідіолу, каннабігеролу і каннабіхромену з використанням цінних колекційних зразків.

Ключові слова: селекція, сорт, мутагенез, інцухт, канабіноїди, продуктивність.

\section{ИЗМЕНЧИВОСТЬ ПРИЗНАКА СОДЕРЖАНИЯ КАННАБИНОИДОВ В ЗАВИСИМОСТИ ОТ СЕЛЕКЦИОННЫХ ПРИЕМОВ}

Лайко И.М., Мищенко С.В., Кириченко А.И.

Институт лубяных культур НААН, Украина

Цель и задачи исследований. Выявить новые возможности проявления генотипов конопли для получения исходного материала с повышенным содержанием непсихотропных каннабиноидов, отсутствием тетрагидроканнабинола и стабилизированными биологическими признаками.

Материал и методы. В своих исследованиях мы исходили из того, что за основу брали украинские сорта конопли, популяции которых отличались высокой стабильностью по признаку содержания каннабиноидов, в сравнении с зарубежными сортообрацами. Исследования проводили с использованием селекционных, биохимических и статистических методов: физического мутагенеза, инцухтирования, индивидуального отбора, тонкослойной и газожидкостной хроматографии для оценки растений по наличию каннабиноидов (хроматограф HP 6890 Series Hewlett Packard с использованием внутреннего стандарта).

Обсуждение результатов. Установлено, что обработка гамма-лучами в дозе 200 Гр приводит к нарушениям генотипических взаимосвязей между каннабиноидами с проявлением их минимальных и максимальных количеств. Понижение дозы облучения до 150 Гр не дестабилизирует популяцию по содержанию каннабиноидов.

Метод инцухтирования также может быть применен в селекции при создании инцухтлиний, гомозиготных как по признаку отсутствия каннабиноидов, так и для выявления линий с повышенным содержанием каннабидиола, каннабигерола, каннабихромена.

У многих сортообразцов ранней и современной селекции конопли (французские, польские, венгерские, немецкие) отмечается высокая популяционная изменчивость признака наличия каннабиноидов, что доказывает отсутствие системной селекционной работы на стабилизацию этих признаков в популяции. Высокой однородностью популяций по формированию и накоплению каннабиноидов отличаются только сорта однодомной конопли селекции Института лубяных культур НААН.

Гомозиготность популяции в первую очередь зависит от факторов контролирования направленного переопыления между растениями с полным отсутствием каннабиноидов посредством проведения экспресс-метода растений на наличие этих соединений до начала цветения и последующим анализом отобранных элитных растений методом тонкослойной хроматографии.

В связи с актуальностью создания сортов конопли с терапевтическими свойствами были разработаны методы селекции на изменение баланса отсутствия всех каннабиноидов в сторону генетически обусловленного увеличения одного из непсихотропных каннабиноидов: каннабидиола, каннабигерола, каннабихромена с отсутствием психотропной активности (наличие тетрагидроканнабинола не превышает 0,08 \%).

Исследованиями процессов накопления каннабиноидов были выявлены отличия в биологии формирования их в течение вегетации. Исходя из того, что максимальное накопление каннабиноидов приходится на фазу начала созревания семян и, в частности, их наибольше синтезируется в околоцветниках и мелких листьях, можно определить перспективность создания сортов конопли с разветвленным соцветием ромбовидной фор- 
мы, что будет обеспечивать наряду с высоким содержанием того или иного каннабиноида еще и повышенный урожай растительной биомассы.

Выводы. Физический мутагенез, инцухтирование и отбор являются перспективными селекционными приемами снижения психотропного тетрагидроканнабинола, стабилизации популяций сортов конопли по отсутствию каннабиноидов, повышения содержания каннабидиола, каннабигерола и каннабихромена с использованием ценных коллекционных образцов.

Ключевые слова: селекция, сорт, мутагенез, иниухт, каннабиноиды, продуктивность.

\section{VARIABILITY OF CANNABINOID CONTENTS DEPENDING ON BREEDING METHODS}

Laiko I.M., Mishchenko S.V., Kyrychenko A.I.

Institute of Bast Crops NAAS, Ukraine

Purpose and objectives. To reveal new possibilities for the expression of cannabis genotypes to obtain starting material with increased contents of non-psychotropic cannabinoids, without tetrahydrocannabinol and stabilized biological traits.

Material and methods. In our study, we took Ukrainian hemp cultivars, the populations of which were distinguished by high stability of cannabinoid contents in comparison with foreign cultivars, as a basis. The study was carried out using breeding, biochemical and statistical methods: physical mutagenesis, inbreeding, individual selection, thin-layer and gas-liquid chromatography to evaluate plants for cannabinoids (HP 6890 Series Hewlett Packard chromatograph using an internal standard).

Results and discussion. It was found that gamma rays at a dose of 200 Gy disrupted the genotypic relationships between cannabinoids, with accumulation of their minimum or maximum amounts. Lowering the irradiation dose to 150 Gy does not destabilize the population in terms of the cannabinoid contents.

Inbreeding can be also used in breeding for both to create inbred lines that are homozygous for the „no cannabinoidse trait and to identify lines with increased contents of cannabidiol, cannabigerol or cannabichromen.

A lot of early-bred and modern cultivars (French, Polish, Hungarian, German) show a high population variability of the cannabinoid contents, proving that no systemic breeding was conducted to stabilize these traits in the populations of these cultivars. High homogeneity of populations in terms of the formation and accumulation of cannabinoids is only intrinsic to monoecious hemp cultivars bred by the Institute of Bast Crops of NAAS.

The homozygosity of a population primarily depends on the control of targeted cross-pollination between cannabinoid-free plants using an express testing plants for these compounds prior to anthesis onset and subsequent analysis of the selected elite plants by thin-layer chromatography.

Given the relevance of creating hemp varieties with therapeutic properties, breeding methods have been developed to shift the balance of ,no cannabinoid at all ${ }^{\text {le }}$ towards a genetically determined increase in one of the cannabinoids (cannabidiol, cannabigerol, cannabichromene) combined with eliminated psychotropic activity (the THC content does not exceed $0.08 \%$ ).

Studies of cannabinoid accumulation revealed differences in their formation during the growing period. Based on the fact that the maximum accumulation of cannabinoids occurs during the seed ripening onset, and, in particular, their synthesis is the most intensive in perianths and small leaves, it is possible to evaluate the prospects for creating hemp cultivars with a branched diamond-shaped inflorescence, which will provide, in addition to a high content of one or another cannabinoid, an increased yield of plant biomass. 
Conclusions. Physical mutagenesis, inbreeding and selection are promising breeding methods for reducing psychotropic tetrahydrocannabinol, stabilizing cannabis cultivars in terms of the absence of cannabinoids, increasing the contents of cannabidiol, cannabigerol and cannabichromene gaining advantage from valuable collection accessions.

Key words: breeding, cultivar, mutagenesis, inbreeding, cannabinoids, performance. 